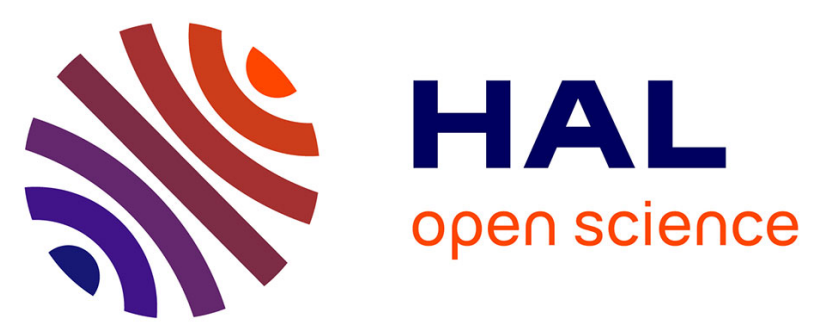

\title{
Response to the comment by A. Salhi (2020) regarding the published article 'Local Risk Awareness and Precautionary Behaviour in a Multi-Hazard Region of North Morocco.'
}

Ante Ivčević, Raquel Bertoldo, Hubert Mazurek, Lionel Siame, Séverin

Guignard, Abdelkhalak Ben Moussa, Olivier Bellier

\section{To cite this version:}

Ante Ivčević, Raquel Bertoldo, Hubert Mazurek, Lionel Siame, Séverin Guignard, et al.. Response to the comment by A. Salhi (2020) regarding the published article 'Local Risk Awareness and Precautionary Behaviour in a Multi-Hazard Region of North Morocco.. International Journal of Disaster Risk Reduction, 2021, pp.102038. 10.1016/j.ijdrr.2021.102038 . hal-03108754

\section{HAL Id: hal-03108754 \\ https://hal-amu.archives-ouvertes.fr/hal-03108754}

Submitted on 13 Jan 2021

HAL is a multi-disciplinary open access archive for the deposit and dissemination of scientific research documents, whether they are published or not. The documents may come from teaching and research institutions in France or abroad, or from public or private research centers.
L'archive ouverte pluridisciplinaire HAL, est destinée au dépôt et à la diffusion de documents scientifiques de niveau recherche, publiés ou non, émanant des établissements d'enseignement et de recherche français ou étrangers, des laboratoires publics ou privés.

\section{(1) (1) $\$$}

Distributed under a Creative Commons Attribution - NonCommercial - NoDerivatives 44.0 
Response to the comment by A. Salhi (2020) regarding the published article 'Local Risk Awareness and Precautionary Behaviour in a Multi-Hazard Region of North Morocco.'

Ante Ivčević*12, Raquel Bertoldo ${ }^{3}$, Hubert Mazurek ${ }^{1}$, Lionel Siame², Séverin Guignard ${ }^{4}$, Abdelkhalak Ben Moussa ${ }^{5}$, Olivier Bellier ${ }^{2}$

In a comment on our manuscript recently published in this journal [1], Salhi (2020) raises concerns about the manuscript and the study on which it was based, concluding that the article provides a distorted picture of the reality in the study area'. The points raised by the comment are mainly dealing with the literature review and methodological issues related with sampling, and finally little on the content and the results.

Our methodological framework was developed under the control of the French research programme 'RiskMed' funded by the Labex OT-Med. Therefore, it was validated by experienced and high-level senior researchers from different research groups, including LPED and CEREGE that are interdisciplinary and internationally recognised for their work on natural hazards and risk assessment. In his comment, Salhi (2020) compared our methodology with the random sampling technique he is familiar with. Although we recognize this alternative approach, our study adopted a methodology that is well-used in social psychology, relying on a sampling strategy that is regular in the field of environmental psychology [2,3]. While our research project was interdisciplinary, gathering researchers from geosciences, geography and psychology, this paper is a thus a standard research in the field of social psychology, based on an approach approved by our partners with the relevant experience with methodology of social sciences.

Convenience sampling is a type of non-probability sampling that involves the sample being drawn from the part of the population that is close to hand [4-6]. Mostly used for pilot testing and common practice for testing basic psychological mechanisms, we found it convenient because of the main objective that was an initial, pilot insight into local awareness. This type of sample technique is wellsuited for testing basic psychological mechanisms [7], being fit for the exploratory purpose of this paper, and thus allowed reaching our objective of having an insight in what sort of elements pertaining to individuals' risk awareness are associated with individual and collective action for risk preparedness.

In a recent paper, Salhi et al. (2020) applied an approach allowing bridging the gap of perception in soil protection actions. At the time of our paper being submitted and revised, this publication was unfortunately not yet available [8]. Relying on an impressive number of farm households that the authors managed to select in 36 villages during a period of 5 years, this study particularly underlines

\footnotetext{
${ }^{1}$ Aix Marseille Univ, IRD, LPED, Marseille, France

${ }^{2}$ Aix Marseille Univ, CNRS, IRD, INRAE, Coll France, CEREGE, Aix-en-Provence, France

${ }^{3}$ Aix-Marseille Univ, LPS, Aix-en-Provence, France

${ }^{4}$ Aix Marseille Univ, Université Côte d'Azur, Avignon Université, CNRS, ESPACE, UMR 7300, Avignon, France

${ }^{5}$ Département de Géologie, Faculté des Sciences de Tétouan, Université Abdelmalek Essaâdi, Tétouan, Morocco

*corresponding author: Ante Ivčević, Aix-Marseille Université, St Charles, case 10, 3 place Victor Hugo, 13331 Marseille Cedex 3, France; email : ante.ivcevic@univ-amu.fr
} 
the difficulty to compare such different approaches like the synchronic and diachronic ones. Actually, our approach integrated questionnaires, field observations and interviews collected during only one month (November 2018) and in eight towns.

Concerning the literature review, the complementary literature provided in the comment is indeed relevant. However, we would like to stress that hundred references including dozens of official reports from national and regional administrations cannot be included in a research paper. Conversely, we carefully chose the references that were central to precise the research questions we investigated in our manuscript. Regarding the critique dealing with the status of Oued Laou, naming it urban or rural depends on whether we consider the standard definition or the function that the municipality plays in relation to the surroundings.

More importantly, we cannot agree with the qualification of our article being "imprecise, vast generalities applicable almost everywhere". Actually, in our paper we focused on both social and physical characteristics of the region, distinguishing three areas: the Atlantic coast, the Mediterranean coast and Martil River valley, as well as the Rif mountains. We also referred to social setting and the ethnic group Amazigh. Along with the history of hazards in the region, mainly the earthquakes and floods, it makes the chosen terrain a very specific site to study. The collaboration between the universities of Tétouan, Nice and Aix-Marseille has lasted for many years, allowing our interdisciplinary consortium to know very well the terrain of North Morocco. Given the quality of the researchers involved in this programme, their scientific rigour and their publication records in various fields, we deeply regret the allegations of this comment, insinuating that we are working with pure imagination.

Acknowledgments:

This project has received funding from the European Union's Horizon 2020 research and innovation programme under the Marie Skłodowska-Curie grant agreement No713750. Also, it has been carried out with the financial support of the Regional Council of Provence- Alpes-Côte d'Azur and with the financial support of the A*MIDEX (n॰ANR-11-IDEX-0001-02), funded by the Investissements d'Avenir project funded by the French Government, managed by the French National Research Agency (ANR). This work has also been funded by the Labex OT-Med (ANR-11-LABEX-0061) supported by the Investissements d'Avenir, French Government project of the French National Research Agency (ANR) through the $A^{*}$ Midex project (ANR-11-IDEX-0001-02).

References:

[1] Ivčević, A., Bertoldo, R., Mazurek, H., Siame, L., Guignard, S., Moussa, A.B. and Bellier, O., 2020. Local risk awareness and precautionary behaviour in a multi-hazard region of North Morocco. International Journal of Disaster Risk Reduction, 50, p.101724.

[2] Dardenne, B., Haslam, A., McGarty, C. and Yzerbyt, V., 2001. La recherche en psychologie.

[3] Lorenzi-Cioldi, F., 1997. Questions de méthodologie en sciences sociales. Actualités en sciences sociales. pp 304

[4] Rego, I.E., Pereira, S.M., Morro, J. and Pacheco, M.P., 2018. Perceptions of seismic and volcanic risk and preparedness at São Miguel Island (Azores, Portugal). International journal of disaster risk reduction, 31, pp.498-503.

[5] Rego, I.E., Pereira, S.M. and Pacheco, M.P., 3. People, places and volcanoes. A study on risk perception in the Azores (Portugal). Geographies of the Anthropocene, p.51. 
[6] Etikan, I., Musa, S.A. and Alkassim, R.S., 2016. Comparison of convenience sampling and purposive sampling. American journal of theoretical and applied statistics, 5(1), pp.1-4.

[7] Siegrist, M. and Cvetkovich, G., 2000. Perception of hazards: The role of social trust and knowledge. Risk analysis, 20(5), pp.713-720.

[8] Salhi, A., et al., Bridging the gap of perception is the only way to align soil protection actions. Sci Total Environ, 2020. 718: p. 137421 